\title{
Pijat teknik marmet pada post partum dan produksi ASI
}

\author{
Dewi Yustianti ${ }^{1}$, Susilawati2* ${ }^{2}$, Dessy Hermawan ${ }^{3}$
}

\author{
1BPM Nurhayati, S.ST Desa Jati Mulyo Kecamatan Jati Agung Kabupaten Lampung Selatan \\ 2Program Studi DIV Kebidanan Fakultas Kedokteran Universitas Malahayati. \\ *Email: susilawati_samaly@yahoo.com \\ 3Program Studi IImu Keperawatan Fakultas Kedokteran Universitas Malahayati
}

\section{Abstract \\ The effect of marmet technique and breast milk production in postpartum}

Background: Breast milk coverage in Indonesia is only $42 \%$. This figure is clearly below the WHO target which requires coverage of breast milk up to $50 \%$. The inability of breastfeeding mothers can be prevented by teaching appropriate techniques to expedite the release of breast milk, one of which is the technique of marmet which is a massage using two fingers that can stimulate the hormone oxytocin to produce milk.

Purpose: Knowing the effect of marmet technique and breast milk production in postpartum.

Methods: This type of quantitative research with quasi-experimental research designs or quasi-experimental with two groups pretest-posttest. The study population of post partum at community medical center (BPM Nurhayati, S.ST) Jati Agung Sub district, South Lampung Regency of 56 post partum mothers and 30 samples. 15 samples treated marmet technique and 15 as comparison groups. The technique sample with accidental sampling. Analysis data of univariate and bivariate t-test.

Results: There was a significant difference before and after the Marmet technique shows the highest significant was after the Marmet technique because of the meanest values with a difference of 40.63 milliliters of Breast milk and t-test results 11.398 and $p$-value $0.000<0.05$.

Conclusion: There was a significant influence before and after the technique of Marmet on breast milk Production in Post Partum.

\section{Keywords: Breast Milk Production; Marmet technique; Postpartum}

Pendahuluan: Cakupan ASI di Indonesia hanya 42\%. Angka ini jelas berada di bawah target WHO yang mewajibkan cakupan ASI hingga $50 \%$. Ketidakmampuan ibu menyusui dapat dicegah dengan mengajarkan teknik yang sesuai untuk memperlancar pengeluaran ASI, salah satunya dengan teknik marmet yang merupakan pijitan dengan menggunakan dua jari yang dapat merangsang hormone ositosin untuk memproduksi ASI.

Tujuan: Diketahui pengaruh tekhnik marmet terhadap peningkatan produksi ASI pada ibu post partum.

Metode: Jenis penelitian kuantitatif dengan rancangan penelitian quasi eksperimen atau eksperimen semu dengan two group pretest-postest. Populasi penelitian ibu post partum di BPM Nurhayati, S.ST Kecamatan Jati Agung Kabupaten Lampung Selatan sebanyak 56 ibu post partum dan sampel sebanyak 30 ibu. Dimana dibagi 2 kelompok, 15 ibu dilakukan perlakuan (teknikmarmet) dan 15 ibu sebagai kelompok pembanding. Teknik sampel dengan acidental sampling. Analisa data univariat dan bivariat uji $t$ (t-test).

Hasil: Ada perbedaan yang signifikan sebelum dan sesudah teknik Marmet menunjukan signifikan tertinggi terdapat pada sesudah teknik Marmet karena sesudah teknik Marmet mempunyai nilai mean paling banyak dengan perbedaan sebanyak 40,63 mililiter ASI dan hasil t-test 11,398 dan nilai $p$-value $0,000<0,05$.

Simpulan: Ada pengaruh yang signifikan sebelum dan sesudah teknik marmet terhadap produksi ASI pada ibu post partum.

\section{Kata kunci: Produksi ASI; Teknik Marmet; Post partum}

\section{PENDAHULUAN}

Menyusui merupakan kejadian alamiah, namun untuk dapat berhasil menyusui dengan optimal, seorang ibu harus mengetahui tentang air susu ibu
(ASI) itu sendiri serta penatalaksanaan menyusui. Kegagalan menyusui sering disebabkan karena faktor psikologis ibu pada hari-hari awal proses 
Pijat teknik marmet pada post partum dan produksi ASI

menyusui. Ibu sering merasa takut kalau ASI yang dihasilkan tidak mencukupi kebutuhan bayinya. Idealnya, proses menyusui dapat dilakukan segera setelah bayi dilahirkan. Bayi yang lahir cukup bulan memiliki naluri untuk menyusu 20 - 30 menit setelah dilahirkan. Pada jam-jam pertama, bayi relatif tenang dan memiliki keinginan untuk menyusu. Namun, kenyataan di lapangan menunjukkan banyak ibu yang mengalami ketidakefektifan proses menyusui karena produksi dan ejeksi ASI yang sedikit di hari-hari pertama sehingga ibu enggan untuk menyusui bayinya (Widiastuti, Arifah, \& Rachmawati, 2015).

ASI (Air susu ibu) merupakan asupan yang sangat penting bagi bayi. Para ibu di seluruh dunia untuk menyusui bayi mereka secara eksklusif selama enam bulan pertama agar mencapai pertumbuhan, perkembangan dan kesehatan secara optimal (World Health Organization, 2013). Bayi yang diberikan ASI eksklusif saja, dan tidak ada makanan lain atau cairan, selama enam bulan memiliki beberapa keunggulan dibandingkan ASI eksklusif selama 3-4 bulan diikuti dengan menyusui campuran (Kramer, \& Kakuma, 2004).

Tidak jauh berbeda dengan program sebelumnya, Sustainable Development Goal's (SGD's) juga menindaklanjuti program Millenium Development Goal's (MDG's) yang belum maksimal. Perbaikan gizi merupakan program nomor dua dari 17 program SDG's yang ditarget dapat berhasil pada tahun 2030 (United Nations General Assembly, 2015). Gizi sejak usia dini atau saat bayi berpengaruh pada kehidupan selanjutnya. Gizi yang cukup selama masa bayi sangat penting untuk kesejahteraan dan kesehatan seumur hidup. Oleh karena itu, bayi harus mendapatkan nutrisi yang memadai dan aman untuk makanan pendamping sambil terus menyusui sampai dua tahun atau lebih untuk memenuhi kebutuhan gizi mereka berkembang (World Health Organization, 1983; Marriott, White, Hadden, Davies, \& Wallingford, 2012).

Cakupan ASI di Indonesia hanya $42 \%$. Angka ini jelas berada di bawah target WHO yang mewajibkan cakupan ASI hingga $50 \%$. Dengan angka kelahiran di Indonesia mencapai 4,7 juta per tahun, maka bayi yang memperoleh ASI, selama enam bulan hingga dua tahun, tidak mencapai dua juta jiwa. Walau mengalami kenaikan dibanding data tahun 2007 dengan angka cakupan ASI hanya 32 persen, cakupan tahun ini tetap memprihatinkan (World Health Organization, 2014; Kementerian Kesehatan Republik Indonesia, 2014). Ketidakmampuan ibu menyusui dapat dicegah dengan mengajarkan teknik yang sesuai untuk memperlancar pengeluaran ASI maupun meningkatkan produksi ASI. Teknik marmet digunakan untuk mengeluarkan ASI. Teknik ini memberikan efek relaks dan juga mengaktifkan kembali reflex keluarnya air susu/Milk Ejection Reflex (MER) (Sears, 2013). Teknik marmet melakukan pijitan dengan menggunakan dua jari, ASI bisa keluar lancar dan membutuhkan waktu sekitar masing-masing payudara 15 menit (Katili, 2011).

Hakikatnya, tidak ada ibu yang memproduksi ASI sedikit. Dari 100 ibu bersalin, hanya dua ibu yang benar-benar memiliki produksi ASI sedikit dan yang lainnya memiliki produksi ASI yang banyak. Ibu perlu mendapatkan penatalaksanaan dini supaya ibu dapat memahami hal-hal penting yang dapat meningkatkan produksi ASI serta upaya agar pengaliran ASI dapat berhasil dengan baik (Asiyah, Rahayu, \& Akhiriyanti, 2012).

ASI terlambat diproduksi akibat pengaruh dari hormon prolaktin dan hormon oksitosin. Hormon prolaktin dan hormon oksitosin mempengaruhi memproduksi dan mengeluarkan ASI. Proses pengeluaran ASI terjadi ketika hormon oksitosin dilepaskan dari kalenjar hipofisis posterior sebagai respon terhadap isapan bayi. Kemudian menstimulasi sel epitel dalam alveoli untuk berkontraksi dan mengeluarkan air susu melewati saluran sinus laktiferus dan merangsang prolaktin (Reeder, Martin, \& Griffin, 2012). Pemberian rangsangan pada otot-otot payudara akan membantu merangsang hormon prolaktin untuk membantu memproduksi air susu. Jumlah prolaktin yang disekresi dan jumlah susu yang diproduksi berkaitan dengan stimulus isapan, yaitu frekuensi, intensitas, dan lamanya bayi menghisap. Isapan bayi akan merangsang susunan saraf disekitarnya dan meneruskan rangsangan ini ke otak, yakni hipofisis anterior sehingga prolaktin disekresi dan dilanjutkan hingga ke hipofisis posterior sehingga sekresi oksitosin meningkat yang menyebabkan otot-otot payudara berkontraksi dan pengeluaran ASI dipercepat (Bobak, Lowdermilk, Jensen, \& Perry, 2005).

Dewi Yustianti' BPM Nurhayati, S.ST Desa Jati Mulyo Kecamatan Jati Agung Kabupaten Lampung Selatan Susilawati ${ }^{2 *}$ Program Studi DIV Kebidanan Fakultas Kedokteran Universitas Malahayati.

*Email: susilawati_samaly@yahoo.com

Dessy Hermawan ${ }^{3}$ Program Studi llmu Keperawatan Fakultas Kedokteran Universitas Malahayati 
Pijat teknik marmet pada post partum dan produksi ASI

Penelitian terdahulu menunjukkan ada pengaruh pijat oksitosin terhadap produksi ASI pada ibu nifas (Maita, 2016). Cloe Marmet atau teknik marmet perpaduan antara memijat dan memerah. Memerah menggunakan tangan dan jari mempunyai keuntungan karena tekanan yang kita gunakan bisa diatur. Selain itu, teknik ini sangat praktis dan ekonomis karena cukup mencuci tangan dan jari sebelum melakukan teknik ini (Roesli, 2013). Ada pengaruh terhadap produksi ASI yang menyebabkan pengeluaran ASI lebih lancar (Widiastuti, Arifah, \& Rachmawati, 2015). Menggabungkan teknik marmet dan pijat oksitosin yang hasilnya ibu yang dilakukan teknik ini 11,5 berpeluang lebih besar mempunyai produksi ASI yang lebih lancar (Mardiyaningsih, Setyowati, \& Sabri, 2011).

Jika menyusui di periode awal kelahiran tidak dapat dilakukan, upaya yang dapat dilakukan sebagai alternatif terbaik berikutnya adalah memerah atau memompa ASI selama $10-20$ menit tiap dua sampai tiga jam sekali hingga bayi dapat menyusu. Tindakan ini dapat membantu memaksimalkan reseptor prolaktin dan meminimalkan efek samping dari tertundanya proses menyusui pada bayi (Astuti, Judistiani, Rahmiati, \& Susanti, 2015).

Teknik marmet merupakan kombinasi cara memerah ASI dan memijat payudara sehingga refleks ASI dapat optimal. Teknik memerah ASI dengan cara marmet bertujuan untuk mengosongkan ASI dari sinus laktiferus yang terletak di bawah areola sehingga diharapkan dengan mengosongkan ASI pada sinus laktiferus akan merangsang pengeluaran prolaktin. Pengeluaran hormon prolaktin diharapkan akan merangsang mammary alveoli untuk memproduksi ASI. Semakin banyak ASI dikeluarkan atau dikosongkan dari payudara akan semakin baik produksi ASI di payudara (Astuti, \& Sari, 2017).

Produksi ASI yang terhambat dan jumlah ASI yang tidak cukup bisa dikarenakan kurangnya dukungan suami yang diberikan pada ibu sehingga ibu kesulitan untuk menyusui dini (Patel \& Gedam, 2013). Perasaan ibu yang merasa sangat dicintai, senang, bahagia, dan mendengar tangisan bayinya lalu memeluk dan mencium bayinya juga berpengaruh meningkatkan produksi ASI (Roesli, 2013). Penelitian juga dilakukan guna mengetahui dukungan keluarga terhadap produksi ASI, suami yang mendukung ibu menyusui berpengaruh terhadap pengeluaran ASI (Ramadani, \& Hadi, 2010).

Pengeluaran ASI pada ibu post partum sebelum dilakukan teknik marmet sebagian besar tidak lancar. Pengeluaran ASI pada ibu post partum sesudah dilakukan teknik marmet sebagian besar lancar. Ada pengaruh teknik marmet terhadap pengeluaran asi pada ibu post partum (Astuti, \& Sari, 2017).

\section{METODE PENELITIAN}

Jenis penelitian kuantitatif, rancangan penelitian quasi eksperimen atau eksperimen semu dengan two group pretest-postest. Populasi ibu post partum di BPM Nurhayati, S.ST Kecamatan Jati Agung Kabupaten Lampung Selatan sebanyak 56 ibu post partum. Pengambilan sampel menggunakan teknik proporsional acidental sampling sebanyak 15 ibu nifas hari pertama dan hari ketiga yang dilakukan teknik Marmet dan 15 ibu sebagai kelompok kontrol. Langkah pertama melakukan pretes dengan mengobservasi produksi ASI menggunakan breast pump dan gelas ukur. Pemerahan ASI dilakukan sebelum ibu menyusui bayinya atau minimal 2-3 jam setelah penyusuan sebelumnya guna mengembalikan produksi ASI ibu pada volume sebelum disusukan ke bayinya. Pretest tersebut dilakukan pada pagi hari setelah sebelumnya dilakukan kontrak waktu dan meminta ibu untuk mengkonsumsi makanan. Kemudian peneliti melakukan teknik marmet selama 3 hari 3 kali/hari) setiap kai Payudara terasa penuh dengan mengkombinasi antara cara memerah ASI dan memijat payudara sehingga refleks keluarnya ASI dapat optimal. Langkah terakhir melakukan postes di hari ketiga dengan mengobservasi kembali produksi ASI menggunakan breast pump dan gelas ukur, serta mencatatnya di lembar observasi. Selanjutnya menguji perubahan-perubahan yang terjadi setelah adanya perlakuan dengan uji t-tes.

\footnotetext{
Dewi Yustianti' BPM Nurhayati, S.ST Desa Jati Mulyo Kecamatan Jati Agung Kabupaten Lampung Selatan Susilawati ${ }^{2 *}$ Program Studi DIV Kebidanan Fakultas Kedokteran Universitas Malahayati.

*Email: susilawati_samaly@yahoo.com

Dessy Hermawan ${ }^{3}$ Program Studi llmu Keperawatan Fakultas Kedokteran Universitas Malahayati
} 
HASIL

Tabel 1. Karakteristik Demografi Responden ( $\mathrm{N}=30)$.

\begin{tabular}{llll}
\hline Demografi & n & $\%$ & $M \pm S D$
\end{tabular}

Usia (Tahun)(Rentang: 20-49)
Postpartum (Hari)(Rentang: 3-38)

Pendidikan

Pekerjaan

Produksi ASI

$\begin{array}{lcc}\text { SD } & 4 & 13.3 \\ \text { SMP } & 12 & 40.0 \\ \text { SMA } & 12 & 40.0 \\ \text { Perguruan Tinggi } & 2 & 6.7 \\ & & \\ \text { Tidak bekerja } & 24 & 80.0 \\ \text { IRT } & 2 & 6.7 \\ \text { Pegawai Swasta } & 4 & 13.3\end{array}$

Kelompok Intervensi

- Sebelum (3-12)

- Sesudah (24-74)

Kelompok Kontrol

- Sebelum (4-14)

- Sesudah (20-40)
$29.17 \pm 7.61$

$16.50 \pm 9.47$

$\begin{array}{ll}30 & 29.17 \pm 7.61 \\ 30 & 16.50 \pm 9.47\end{array}$

13.3

6.7

80.0

13.3
$8.20 \pm 2,513$

$44,67 \pm 13.388$

$8.87 \pm 3.021$

$26.93 \pm 5.599$

Berdasarkan tabel 1. diatas diketahui responden berusia antara 20 sampai 49 tahun dengan mean sebesar 29.17 dan standar deviasi 7.61. Hari lamanya postpartum dari hari ke-3 sampai hari ke-38 dengan mean sebesar 16.50 dan standar deviasi 9.47. Riwayat pendidikan responden yang terbanyak adalah SMP(40.0\%) dan SMA $(40.0 \%)$. Adapun responden didominasi yang tidak bekerja (80.0\%). Rata-rata produksi ASI sebelum teknik Marmet adalah 8,2 mililiter dengan jumlah minimal 3 mililiter dan maksimal 12 mililiter dalam satu kali pengambilan. Diketahui rata-rata produksi ASI pada kelompok kontrol adalah 8.87 mililiter dengan jumlah minimal 4 mililiter dan maksimal 14 mililiter dalam satu kali pengambilan. Sedangkan, diketahui rata-rata produksi ASI Sesudah teknik Marmet adalah 44.67 mililiter dengan jumlah minimal 24 mililiter dan maksimal 74 mililiter dalam satu kali pengambilan. Diketahui rata-rata produksi ASI pada kelompok kontrol adalah 26.93 mililiter dengan jumlah minimal 20 mililiter dan maksimal 40 mililiter dalam satu kali pengambilan.

Tabel 2. Pengaruh Teknik Marmet Terhadap Peningkatan Produksi Asi N=30

\begin{tabular}{lllllll}
\hline Variabel & $\mathbf{N}$ & Mean & SD & t-test & p value & $\mathbf{9 5 \%} \mathbf{C l}$ \\
& & & & & & \\
\hline Kelompok Intervensi & 15 & 36,467 & 12,392 & 11,398 & 0.000 & $29,604-43,329$ \\
Kelompok Kontrol & 15 & 18.067 & 5.898 & 11.865 & 0.000 & $21.333-11.865$ \\
\hline
\end{tabular}

Berdasarkan tabel 2. diketahui Hasil uji statistik didapatkant-test 17,169 dan nilai p-value 0,000 $<0,05$ maka dapat disimpulkan ada pengaruh yang signifikan pada sebelum teknik Marmet dan sesudah teknik Marmet, terlihat peningkatan produksi ASI pada ibu yang dilakukan teknik marmet sebesar $36.4 \mathrm{ml}$ sedangkan pada kelompok kontrol peningkatan produksi ASI sebesar $18,0 \mathrm{ml}$.

Dewi Yustianti' BPM Nurhayati, S.ST Desa Jati Mulyo Kecamatan Jati Agung Kabupaten Lampung Selatan Susilawati $^{2 *}$ Program Studi DIV Kebidanan Fakultas Kedokteran Universitas Malahayati.

*Email: susilawati_samaly@yahoo.com

Dessy Hermawan ${ }^{3}$ Program Studi llmu Keperawatan Fakultas Kedokteran Universitas Malahayati 
Pijat teknik marmet pada post partum dan produksi ASI

\section{PEMBAHASAN}

\section{Rata-Rata Produksi ASI Sebelum Intervensi}

Berdasarkan tabel 1 diatas diketahui rata-rata produksi ASI sebelum teknik Marmet adalah 7,7 mililiter dengan jumlah minimal 3 mililiter dan maksimal 12 mililiter dalam satu kali pengambilan. Diketahui rata-rata produksi ASI pada kelompok kontrol adalah 8,87 mililiter dengan jumlah minimal 4 mililiter dan maksimal 14 mililiter dalam satu kali pengambilan.

Air Susu Ibu (ASI) berupa emulsi lemak dalam larutan protein, laktosa dan garam-garam anorganik yang disekresikan oleh kelenjar mamae ibu, dan berguna sebagai makanan bayi. ASI dibedakan menjadi tiga stadium yaitu kolostrum, asi susu transisi dan air susu matur. Kolostrum sebagai air susu yang pertama kali keluar berwarna kekuningan mengandung banyak protein, antibodi, dan immunoglobulin. ASI transisi keluar setelah kolostrum sampai sebelum ASI matang, yaitu sejak hari ke-4 sampai hari ke-10 yang mengandung protein semakin rendah sedangkan kadar lemak dan karbohidrat semakin tinggi. ASI matur disekresikan pada hari ke sepuluh dan seterusnya berwarna puth kekuningan (Maryunani, 2015).

Volume ASI yang diproduksi dan dikeluarkan oleh kelenjar payudara dapat berbeda berdasarkan faktor-faktor yang mempengaruhinya (Astutik, 2017). Produksi ASI yang akan dihasilkan ibu pada kelenjar payudaranya tidaklah sama setiap wakunya. Dikatakan bahwa volume ASI akan menurun sesuai dengan waktu (Wiji, 2013).

Produksi ASI sangat dipengaruhi oleh hormon prolaktin yang akan menproduksi ASI, dan hormon oksitosin yang berpengaruh pada kelancaran pengeluaran ASI, karena semakin ASI keluar produksi ASI akan semakin meningkat, jadi teknik Marmet dapat menstimulasi hormon prolaktin dan oksitosin (Mardiyaningsih, Setyowati, \& Sabri, 2011).

Menurut pendapat peneliti, pikiran dan perasaannya tidak tenang menimbulkan beban fikiran untuk responden yang berakibat pada tidak meningkatnya volume produksi ASI setelah dilakukan teknik Marmet .

\section{Rata-Rata Produksi ASI Sesudah Intervensi}

Berdasarkan tabel 2 diatas diketahui rata-rata produksi ASI Sesudah teknik Marmet adalah 44,57 mililiter dengan jumlah minimal 24 mililiter dan maksimal 74 mililiter dalam satu kali pengambilan. Diketahui rata-rata produksi ASI pada kelompok kontrol adalah 26.93 mililiter dengan jumlah minimal 20 mililiter dan maksimal 40 mililiter dalam satu kali pengambilan

Hormon oksitosin berfungsi memacu kontraksi otot polos yang ada di dinding alveolus dan dinding saluran sehingga ASI dipompa keluar (Wiij, 2013). Refleks oksitosin lebih rumit dibanding refleks prolaktin. Pikiran, perasaan dan sensasi seorang ibu akan sangat mempengaruhi refleks ini. Perasaan ibu dapat meningkatkan dan juga menghambat pengeluaran oksitosin. Hormon ini akan menyebabkan sel-sel otot yang mengelilingi saluran pembuat susu mengerut atau berkontraksi sehingga ASI terdorong keluar dari saluran produksi ASI dan mengalir siap untuk dihisap oleh bayi (Suradi, 2011).

Laktasi atau menyusui proses yang cukup kompleks. Laktasi sebagai produksi (pembuatan) dan pengeluaran ASI (Suradi, 2011). Masssase belakang atau teknik Marmet pada prinsipnya bertujuan membuat otot-otot myopithel berkontraksi, merelaksasikan pikiran dan memperlancar pengeluaran ASI. Pengeluaran ASI ini terjadi karena sel otot halus di sekitar kelenjar payudara mengerut sehingga memeras ASI untuk keluar. ASI dapat keluar dari payudara akibat adanya otot-otot yang mengerut yang dapat distimulasi oleh suatu hormon yang dinamakan oksitoksin. Refleks oksitosin lebih rumit dibanding refleks prolaktin. Pikiran, perasaan dan sensasi seorang ibu akan sangat mempengaruhi refleks ini terutama pada pengeluaran hormon endorphin. Perasaan ibu dapat meningkatkan dan juga menghambat pengeluaran endorphin yang menghasilkan hormon oksitosin. Oksitosin memacu sel-sel myoepithel yang mengelilingi alveoli dan duktuli untuk berkontraksi, sehingga mengalirkan ASI dari alveoli ke duktuli menuju sinus dan puting untuk dihisap oleh bayi (Pangestu, 2017).

\section{Pengaruh Tekhnik Marmet Terhadap Produksi ASI}

Hasil uji statistik didapatkan nilai $p$-value 0,000 $<0,05$ maka dapat disimpulkan ada perbedaan yang signifikan pada sebelum teknik Marmet dan sesudah teknik Marmet. Dari hasil uji ini yang

Dewi Yustianti' BPM Nurhayati, S.ST Desa Jati Mulyo Kecamatan Jati Agung Kabupaten Lampung Selatan Susilawati ${ }^{2 *}$ Program Studi DIV Kebidanan Fakultas Kedokteran Universitas Malahayati.

*Email: susilawati_samaly@yahoo.com

Dessy Hermawan ${ }^{3}$ Program Studi llmu Keperawatan Fakultas Kedokteran Universitas Malahayati 
Pijat teknik marmet pada post partum dan produksi ASI

menunjukan signifikan tertinggi terdapat pada sesudah karena sesudah mempunyai nilai mean paling banyak dengan perbedaan jumlah 44,67 mililiter ASI. Didapatkan hasil yaitu rata-rata volume ASI sebelum teknik Marmet adalah $8,20 \mathrm{ml}$ dan setelah adalah $44,67 \mathrm{ml}$. Dilihat dari volume tersebut, rata-rata masih terbilang sedikit hal ini bisa terjadi dikarenakan upaya-upaya ibu menyusui dalam mengatasi masalah dalam ASI nya belum optimal dan ibu menyusui yang dijadikan responden mengaku belum pernah teknik Marmet.

Berdasarkan Tabel 2 dapat diketahui bahwa dari 30 responden ibu menyusui 0-3 bulan, sesudah diberikan breast care dan Teknik Marmet memiliki rata-rata jumlah produksi ASI sebesar $44,67 \mathrm{ml}$ dengan standar deviasi $12,392 \mathrm{ml}$, produksi ASI paling sedikit sejumlah $29 \mathrm{ml}$ dan paling banyak sejumlah $43 \mathrm{ml}$.

Produksi ASI merujuk pada volume ASI yang dikeluarkan oleh payudara dan banyaknya ASI tersebut diasumsikan sama dengan produksi ASI. Meningkat dan menurunnya produksi ASI dapat dipengaruhi beberapa faktor seperti makanan yang dikonsumsi ibu, ketenangan jiwa dan fikiran, penggunaan alat kontrasepsi, perawatan payudara, anatomis payudara, faktor fisiologis, pola istirahat, faktor isapan anak atau frekuensi penyusuan, berat lahir bayi, umur kehamilan saat melahirkan, dan konsumsi rokok serta alkohol (Wiji, 2013).

Salah satu cara meningkatkan produksi ASI melalui salah satu faktor yang mempengaruhinya dapat dilakukan intervensi berupa teknik Marmet dengan cara pengurutan atau massase diharapkan dapat memberi rangsangan kepada kelenjar air susu ibu agar dapat memproduksi susu tersebut (Pangestu, 2017). Teknik Marmet akan mempercepat kerja saraf parasimpatis merangsang hipofise posterior untuk mengeluarkan oksitosin, dengan tujuan untuk memberi rangsangan kepada kelenjar air susu ibu agar dapat memproduksi susu dan memicu hormon oksitosin atau refleks let down serta memberikan kenyamanan dan menciptakan rasa rileks pada ibu melalui hormon endorphin yang disekresi karena rasa nyaman dan rileks tersebut yang dialami ibu selama teknik Marmet dan support yang diberikan. produksi ASI meningkat melalui rangsangan sentuhan pada punggung ibu akan merangsang produksi oksitosin yang menyebabkan kontraksi sel-sel myophite (Sulistyawati, 2009).

Berdasarkan uji $t$ dependen didapatkan nilai $t$ hitung sebesar 11,398 dengan $p$-value sebesar 0,000 . Terlihat bahwa $p$-menunjukkan bahwa ada perbedaan yang signifikan produksi ASI sebelum dan sesudah dilakukan masase belakang (teknik Marmet) pada ibu menyusui 0-3 bulan. Hasil penelitian sebelum dan sesudah dilakukan metode massase belakang (teknik Marmet), produksi mengalami peningkatan. Peningkatan volume ASI tersebut dapat dilihat dari rata-rata volume ASI sebelum dilakukan masase belakang (teknik Marmet) $8,20 \mathrm{ml}$ menjadi $44,67 \mathrm{ml}$ setelah dilakukan.

Seringkali saat sudah terproduksi ASI tetap tidak dapat dikeluarkan akibat adanya sumbatan maupun kurangnya rangsangan pada otot polos untuk berkontraksi, dengan adanya teknik Marmet langsung pada payudara maka aliran ASI dalam payudara akan lancar dan menyebabkan rangsangan pada otot halus di kelenjar payudara dapat mengeluarkan dan memproduksi ASI dalam jumlah yang banyak untuk memenuhi kebutuhan nutrisi bayi baru lahir (Walyani, \& Purwoastuti, 2015).

Produksi ASI ibu sangat dipengaruhi oleh faktor kejiwaan. Ibu yang selalu dalam keadaan gelisah, kurang percaya diri, rasa tertekan, ketakutan, pengunjung yang tidak simpatik dan berbagai bentuk ketegangan emosional, mungkin akan mengakibatkan ibu gagal dalam menyusui bayinya karena kondisi ini dapat menghambat pengeluaran hormon oksitosin sehingga mencegah masuknya air susu ke dalam pembuluh payudara. Ketentraman jiwa dan pikiran ibu juga dipengaruhi oleh dukungan dari keluarga, suami dan petugas kesehatan (Derek, 2005).

\section{SIMPULAN}

Diketahui rata-rata produksi ASI sebelum teknik Marmet adalah 8,2 mililiter dengan jumlah minimal 3 mililiter dan maksimal 12 mililiter dalam satu kali pengambilan. Rata-rata produksi ASI sesudah teknik Marmet adalah 44,67 mililiter dengan jumlah minimal 24 mililiter dan maksimal 74 mililiter dalam satu kali pengambilan. Ada perbedaan yang signifikan pada sebelum teknik Marmet dan sesudah teknik Marmet, dengan perbedaan

Dewi Yustianti' BPM Nurhayati, S.ST Desa Jati Mulyo Kecamatan Jati Agung Kabupaten Lampung Selatan

Susilawati ${ }^{2 *}$ Program Studi DIV Kebidanan Fakultas Kedokteran Universitas Malahayati.

*Email: susilawati_samaly@yahoo.com

Dessy Hermawan ${ }^{3}$ Program Studi llmu Keperawatan Fakultas Kedokteran Universitas Malahayati 
Pijat teknik marmet pada post partum dan produksi ASI

sebanyak 40,63 mililiter ASI dan hasil t-test 11,398 dan nilai $p$-value $0,000<0,05$ maka dapat disimpulkan ada pengaruh yang signifikan pada sebelum teknik Marmet dan sesudah teknik Marmet.

\section{SARAN}

Diharapkan dapat digunakan sebagai cara dalam peningkatan produksi ASI yang mudah untuk dilakukan tanpa efek yang membahayakan dalam memberikan intervensi dan asuhan keperawatan pada ibu selama masa nifas, serta dapat menerapkan teknik Marmet dengan benar keseluruh ibu bersalin dalam rangka peningkatan mutu pelayanan dan meningkatkan derajat kesehatan pada ibu.

\section{DAFTAR PUSTAKA}

Asiyah, N., Rahayu, Y. P., \& Akhiriyanti, E. N. (2012). Buku Ajar Masa Nifas dan Menyusui. Jakarta: Mitra Wacana Medika.

Astuti, L. P., \& Sari, A. (2017). Pengaruh teknik marmet terhadap pengeluaran asi pada ibu post partum di wilayah kerja Puskesmas Kota Semarang. In Seminar Nasional Kesehatan Reproduksi Menuju Generasi Emas (Vol. 1, No. 1, pp. 95-100).

Astuti, S., Judistiani, R., Rahmiati, L., \& Susanti, A. (2015). Asuhan kebidanan nifas dan menyusui. Jakarta: Erlangga.

Astutik, R. Y. (2017). Payudara dan laktasi. Jakarta: Salemba Medika.

Bobak, I. M., Lowdermilk, D. L., Jensen, M. D., \& Perry, S. E. (2005). Buku ajar keperawatan maternitas. Jakarta: EGC.

Derek, L. J. (2005). Setiap Wanita. Jakarta: PT Delapratasa Publishing.

Katili, A.A. (2011). Nutrisi dan Metabolisme. Jakarta: UI Press.
Kementerian Kesehatan Republik Indonesia. (2014). Situasi dan analisis asi eksklusif. Infodatin Kemenkes RI, 1-8.

Kramer, M. S., \& Kakuma, R. (2004). The optimal duration of exclusive breastfeeding. In Protecting infants through human milk (pp. 63-77). Springer, Boston, MA.

Maita, L. (2016). Pengaruh pijat oksitosin terhadap produksi ASI. Jurnal Penelitian Kesehatan" SUARA FORIKES"(Journal of Health Research" Forikes Voice"), 7(3), 173-175.

Mardiyaningsih, E. Setyowati, \& Sabri, L.(2011). The effectiveness combination marmet technic and oxytocin massage against milk production for post-caesarean section mother in Central Java hospital. Soedirman Nursing Journal, 6(1), 31-38.

Marriott, B. P., White, A., Hadden, L., Davies, J. C., \& Wallingford, J. C. (2012). World Health Organization (WHO) infant and young child feeding indicators: associations with growth measures in 14 low-income countries. Maternal \& child nutrition, 8(3), 354-370.

Maryunani, A. (2015). Inisiasi menyusui dini, ASI eksklusif dan manajemen laktasi. Jakarta: Trans Info Media.

Pangestu, S. (2017). Pengaruh teknik marmet dan pijat oksitosin terhadap produksi asi ibu post partum normal di Rumah Bersalin Mardi Rahayu Semarang. Karya IImiah, 9.

Patel, U., \& Gedam, D. S. (2013). Effect of back massage on lactation among postnatal mothers. International journal of medical research and Review, 1(01).

Dewi Yustianti' BPM Nurhayati, S.ST Desa Jati Mulyo Kecamatan Jati Agung Kabupaten Lampung Selatan Susilawati $^{2 *}$ Program Studi DIV Kebidanan Fakultas Kedokteran Universitas Malahayati.

*Email: susilawati_samaly@yahoo.com

Dessy Hermawan ${ }^{3}$ Program Studi llmu Keperawatan Fakultas Kedokteran Universitas Malahayati 
Pijat teknik marmet pada post partum dan produksi ASI

Ramadani, M., \& Hadi, E. N. (2010). Dukungan suami dalam pemberian asi eksklusif di wilayah kerja puskesmas air tawar kota padang, sumatera barat. Kesmas: National Public Health Journal, 4(6), 269-274.

Reeder, S. J., Martin, L. L., \& Griffin, D. K. (2012). Keperawatan maternitas: Kesehatan wanita, bayi dan keluarga (edisi 18.) EGC: Jakarta.

Roesli, U. (2013). ASI eksklusif. Jakarta: Trubus Agriwidya.

Sears, M. (2013). The baby book, revised edition: Everything you need to know about your baby from birth to age two. Hachette UK.

Sulistyawati, A. (2009). Asuhan kebidanan pada masa kehamilan. Jakarta: Salemba Medika.

Suradi, R. (2011). Menejemen Lakatasi cetakan ke-5. Jakarta: Perinasia.

United Nations General Assembly. (2015). Sustainable Development goals. SDGs), Transforming our world: the, 2030.
Walyani, E. S., \& Purwoastuti, E. (2015). Asuhan Kebidanan Masa Nifas dan Menyusui. Yogyakarta: PT. Pustaka Baru.

Widiastuti, A., Arifah, S., \& Rachmawati, W. R. (2015). Pengaruh Teknik Marmet terhadap Kelancaran Air Susu Ibu dan Kenaikan Berat Badan Bayi. Kesmas: National Public Health Journal, 9(4), 315-319.

Wiji, R. N. (2013). ASI dan panduan ibu menyusui. Yogyakarta: Nuha Medika.

World Health Organization. (1983). Infant and young child nutrition.

World Health Organization. (2013). Country implementation of the international code of marketing of breast-milk substitutes: status report 2011.

World Health Organization. (2014). Global nutrition targets 2025: breastfeeding policy brief (No. WHO/NMH/NHD/14.7). World Health Organization. 